\title{
OPEN GOVERNMENT DATA: CONCEPTS, APPROACHES AND DIMENSIONS OVER TIME
}

\section{DADOS ABERTOS GOVERNAMENTAIS: CONCEITOS, ABORDAGENS E DIMENSÕES AO LONGO DO TEMPO}

\author{
Rodrigo Hickmann Klein \\ Pontifícia Universidade Católica do Rio Grande do Sul - PUC-RS \\ hickmannklein@gmail.com
}

Deisy Cristina Barbiero Klein

Pontifícia Universidade Católica do Rio Grande do Sul - PUC-RS

deisy.klein@gmail.com

Edimara Mezzomo Luciano

Pontifícia Universidade Católica do Rio Grande do Sul - PUC-RS

eluciano@pucrs.br

Submissão: $14 / 07 / 2017$

Aprovação: 26/04/2018

\begin{abstract}
Government Open Data (DAG) is free, open and available data by public organizations and can be used in projects or integrated with new products, applications or services. Research in the OGD area has grown substantially in recent years, addressing several different conceptual approaches and dimensions. It is important to understand the concept over time as a way to better conceive researches based on contemporary approaches. Therefore, the present study aims to review and categorize existing researches about OGD, identifying which approaches are being adopted, which are the research strategies used, how the concept evolves and which are the most referenced articles. This study analyzed and categorized researches about OGD through a systematic literature review covering 193 publications presented in the main databases. Papers were analyzed through content analysis, through the steps of reduction, display, conclusion and double blind verification. The researches were classified into seven dimensions and under ten different approaches. Concurrently with the development of OGD global initiatives, new scientific papers tend to direct their focus to issues such as data quality and accountability. Through the results of this research it is possible to identify widely discussed approaches and those that can be further explored, as well as the development of the OGD concept over time and its dimensions.
\end{abstract}

Keywords: Open Data; Open Government Data; Open Data approaches; Open Data dimensions. 


\section{RESUMO}

Os Dados Abertos Governamentais (DAG) são dados livres, abertos e disponíveis por organizações públicas e podem ser usados em projetos ou integrados a novos produtos, aplicativos ou serviços. A pesquisa na área de DAG cresceu substancialmente nos últimos anos com diferentes abordagens e dimensões conceituais, tornando importante compreender o conceito ao longo do tempo. Portanto, o presente estudo tem como objetivo analisar e categorizar as pesquisas existentes sobre DAG, identificando quais abordagens estão sendo adotadas, quais são as estratégias de pesquisa utilizadas, como o conceito evolui e quais são os artigos mais referenciados. Este estudo analisou e categorizou pesquisas sobre DAG através de uma revisão sistemática da literatura que abrange 193 publicações apresentadas nas principais bases de dados. Os documentos foram analisados através da análise de conteúdo, com etapas de redução, exibição, conclusão e verificação duplo-cego. As pesquisas foram classificadas em sete dimensões e em dez abordagens diferentes. Paralelamente ao desenvolvimento das iniciativas globais da DAG, novos trabalhos científicos tendem a direcionar seu foco para questões como a qualidade dos dados e a responsabilização. Através dos resultados desta pesquisa, é possível identificar abordagens amplamente discutidas e as que podem ser exploradas, bem como o desenvolvimento do conceito DAG ao longo do tempo e suas dimensões.

Palavras-chave: Dado Aberto; Dados Aberto Governamental; Abordadagens ao Dado Aberto; Dimensões do Dado Aberto. 


\section{Introduction}

Open Data is data that can be freely used, reused and redistributed by anyone (ATTARD et al., 2015). Open Data from the public sector, or Open Government Data (OGD), provides useful information for citizens and businesses in their dealings with the public sector (GALIOTOU and FRAGKOU, 2013). OGD is the free, open and available data coming from public organizations and it can be used for public projects or integrated into new products, applications or services, such as navigation systems, weather forecasting, or financial and insurance services (UBALDI, 2013). Therefore, OGD is an important component in supporting data innovation, an approach in which companies analyze data to obtain information about their area of activity, their stakeholders and competitors, or in the development of new services opportunities (O'RIAIN et al. 2012). OGD can also be an important instrument in the fight against corruption, allowing greater transparency in government activities, budgets and expenditures, becoming an important element in various accountability interventions (ATTARD et al., 2015).

In recent years, many Open Government Data (OGD) initiatives have emerged throughout the world, with transparency and the reuse of data as their two main objectives (ATTARD et al., 2015). These initiatives have made a significant amount of public sector information available, free for use and redistribution without restrictions (O'RIAIN et al, 2012.). Their purpose is to improve public accountability, citizen participation, and crosssector collaborative partnerships (LINDERS, 2013).

Open Government Data can help to promote collaboration between public bodies and departments, based on purposes such as the use of available information, collaboration and public information exchange, restructuring optimizations and internal procedures simplification (with possible later processes automation), elimination of redundant expenses and reduction of internal transactional costs (Harrison et al., 2012). Subsequent benefits include a reduction in workload, bureaucracy and transaction costs. The services offered by the government can also be improved because public sector can adjust their services to the citizen's needs with reciprocal benefits provided people can more easily find data and thus claim the benefits they are entitled to (UBALDI, 2013). OGD contributes to social control and the strengthening of democracy, active citizenship, as well as to improvements in public administration, innovation, cooperation, and transparency (HARRISON et al., 2012). However, the data must be in an open format, accessible, machine-readable and should be produced by all and for all (HARRISON et al., 2012).

Research in the Open Government Data (OGD) has grown substantially in recent years, producing several different conceptual approaches that might lead to a more comprehensive understanding of the subject development. This study aims to analyze and categorize researches on open data in order to identify the dimensions and approaches outlined in the research conducted to date, the research strategies used and to understand how the concept evolves. It is possible to identify, through the results of this research, widely discussed approaches and those that can be further explored as well as the development of the OGD concept and its dimensions, which can form the basis for future research.

Therefore, the present study aims to review and categorize existing research about OGD, identifying which approaches are being adopted, which are the research strategies used, how the concept evolves and which are the most referenced articles. However, nongovernmental open data and others data disclosed by government, but not open, are not addressed by this study.

A systematic review of literature was performed in order to achieve the proposed goal, following the recommendations of Cooper et al. (2009) about research steps and structure. In second session, some background concepts about OGD are presented. The procedures to 
select the databases and papers are presented in third session, as well as the description of the phases of identification, screening, eligibility and inclusion, with the number of studies included and excluded at each stage. In the forth section, the results analysis is presented and the characteristics of the covered studies are described, encompassing critical and systematic evaluation. Finally, section five describes the final considerations in the context of previous theories, evidences and practice.

\section{Theoretical Background}

Government data are considered open when published according to eight principles listed by an open government working group designed to address the availability of state information (DAVIES, 2013). These principles were defined in 2007 and are universally accepted by the global community. Thus, governmental data are considered open when published in accordance with such principles as defined below (OGD, 2016):

a) Complete: All public data is made available. Public data is data that is not subject to privacy, security or privilege limitations;

b) Primary: Data is as collected at the source, with the highest possible level of granularity, not in aggregate, summarized or modified forms;

c) Timely: Data is made available as quickly as necessary to preserve its value;

d) Accessible: Data is available to the widest range of people for the widest range of purposes;

e) Machine processable: Data is reasonably structured to allow automated processing;

f) Non-discriminatory: Data is available to anyone, with no requirement of registration;

g) Non-proprietary: Data is available in a format over which no entity has exclusive control;

h) License-free: Data is not subject to any copyright, patent, trademark or trade secret regulation.

Lourenço (2015) attributes to OGD the achievement of two main objectives of open government. The first one is to promote transparency through government data publication, enabling the citizen to see what the government does and allowing the accountability of public agents and representatives of their actions. The second one is to disclose government data and information that can be reused to provide social or economic value. In this way, OGD contributes to social control and strengthening of democracy, by active citizenship, improvements in public administration, innovation, cooperation and transparency (HARRISON et al., 2012). Nevertheless, relationships between information, transparency and democracy are fundamental and basic (HARRISON et al., 2012). Information is essential for development of basic democratic skills, such as formulation of preferences and opinions, formation of hypotheses and citizen participation in decision-making. Without these skills, citizens' voice and exercise of their rights are denied. Attard et al. (2015) contribute by indicating three main reasons for opening of Government Data:

a) Transparency: democratic society, citizens and other interested parties need to be able to monitor government initiatives. Transparency also means that stakeholders can not only access the DAG, but must also be able to use, reuse and distribute them. The success of transparency results in the considerable increase of social control by citizens;

b) Participatory Governance: DAG publication provided to citizens the opportunity to actively participate in governance processes such as decision making and policy formulation, rather than sporadically vote in an election every certain interval of years. Through Government Open Data initiatives stakeholders can also be better informed and able to make better decisions; 
c) Social and commercial value: governments are one of the largest producers and collectors of data in several different domains. All data, such as school addresses, geospatial data, environmental data, transport data, planning data or budget data, have social and commercial value, and can be used for a number of purposes other than originally intended. Publishing such data, governments encourages stakeholders to innovate and create new services.

Scholl (2012) adds that the redefinition of government role as information providers allows society to add new values to data, exploiting potential of use and reuse in production of information of social relevance, based on available open data. Thereby, transparency increases the exposure of government operations to a detailed examination of various components of political system (STAMATI et al., 2015), increasing the chances of corruption detection (ANDERSEN, 2009). However, government data need to be open, accessible, machine-readable, and the information produced from the OGD must be produced to everyone (HARRISON et al., 2012). Kassen (2013) adds that open government data is a concept that involves making government data widely available to anyone but without any copyright restrictions.

According to Yang and $\mathrm{Wu}$ (2016), OGD can be considered as an innovation to help government agencies achieve the principles of open government, including transparency, participation and collaboration. According to Lakomaa and Kallberg (2013), OGD is essential in applications and information services innovations, influencing the innovative process in many ways. In this sense, Hellberg and Hedström (2015) point out that many of policies that addressed the reuse of public data consider OGD as an engine for innovation. For O'Riain et al. (2012), OGD directly supports innovation, since raw government data is analyzed by companies and used to better inform interested parties about their business situations or for development of new service opportunities. Yannoukakou and Araka (2014) add that OGD is primarily aimed at innovation and economic growth, exploiting data to produce new, valueadded products. However, the player's roles are changing with the maturity of this new market segment and may have important policy implications. Increasing of data use can further stimulate by sharing data, sources integrations and better data usability, causing pressure to make available other data types (JANSSEN and ZUIDERWIJK, 2014).

\section{Research Method}

In order to achieve the established objectives, a systematic review of the literature was carried out. Systematic reviews aim to address problems of identification, critical assessment and integration of the findings of all relevant and high quality individual studies addressing one or more research questions. A systematic review can achieve most or all of the following objectives (BAUMEISTER and LEARY, 1997; BEM, 1995): a) to establish to what extent the existing research has progressed to clarify a particular problem; b) to identify relationships, contradictions, gaps and inconsistencies in the literature, exploring reasons, proposing a new conceptualization or theory that explains the inconsistency; c) to formulate general statements or a comprehensive conceptualization; d) to comment, evaluate, expand or develop the theory; e) to provide implications for practice and policy, and f) to describe guidelines for future research.

According to the guidelines of Cooper et al. (2009), the analysis of the articles was composed of seven phases, performed between October 2016 and January 2017. In the first phase we consulted the databases SCOPUS, WEBOFSCIENCE, SCIENCEDIRECT and $S C I E L O$. A starting year was not specified. Table 1 contains the terms, databases, criteria and the quantity of articles found. This first phase resulted in a selection of 608 articles indexed until 12/31/2016. 


\begin{tabular}{|c|c|c|}
\hline \multicolumn{3}{|c|}{ Search term: "OPEN GOVERNMENT DATA" } \\
\hline $\begin{array}{l}\text { Databases } \\
\text { Researched }\end{array}$ & Search criteria & $\begin{array}{c}\text { Number of } \\
\text { studies }\end{array}$ \\
\hline SCOPUS & $\begin{array}{l}\text { In: Article Title, Abstract, Keyword; Document type: Article; } \\
\text { Subject Area: all sciences; All years; }\end{array}$ & 82 \\
\hline SCIENCEDIRECT & $\begin{array}{l}\text { In: Abstract, Title, Keyword; Refine: Journal; All Sciences; All } \\
\text { years; Except: Article status "Corrected Proof". }\end{array}$ & 30 \\
\hline WEB OF SCIENCE & $\begin{array}{l}\text { Topic: "Open Government Data" OR Title: "Open Government } \\
\text { Data"; Document type: Article; All years. }\end{array}$ & 49 \\
\hline SCIELO & All indexes & 5 \\
\hline \multicolumn{3}{|c|}{ Search term: "OPEN DATA" AND GOVERNMENT } \\
\hline $\begin{array}{l}\text { Databases } \\
\text { Researched }\end{array}$ & Search criteria & $\begin{array}{c}\text { Number of } \\
\text { studies }\end{array}$ \\
\hline SCOPUS & $\begin{array}{l}\text { In: Article Title, Abstract and Keyword; Document type: } \\
\text { Article; Subject Area: all sciences; All years. }\end{array}$ & 239 \\
\hline SCIENCEDIRECT & $\begin{array}{l}\text { In: Abstract, Title, Keyword; Refine: Journal; All Sciences; All } \\
\text { years; Except: Article status "Corrected Proof". }\end{array}$ & 48 \\
\hline WEB OF SCIENCE & $\begin{array}{l}\text { Topic: "Open Data" and Government Or Title: "Open Data" and } \\
\text { Government; Document Type: Article; All years. }\end{array}$ & 148 \\
\hline SCIELO & All indexes & 7 \\
\hline
\end{tabular}

\section{Table 1 - Search terms and databases used}

In the second phase, a crosscheck of the articles was performed to identify and remove duplicates. In this phase, the articles originating from events and conferences were also removed, leaving 315 articles. In the third phase the articles were verified, based on article content, to confirm that they really addressed the OGD concept, or the use of OGD. Articles that did not meet these criteria were removed from the selection. Regarding the language, only articles in English were kept. As a result of this phase, 193 articles remained in the selection, which are the basis of this research.

The 193 articles were analyzed in the fourth phase, searching for definitions of Open Government Data or Open Data in Government. In this phase we used the software tool MAXQDA 12 to search using the terms Open Data and Open Government Data. Excerpts of four lines were generated that were coded and analyzed in pairs. In the fifth phase the common terms within each definition of Open Data and Open Government Data were analyzed, through open coding strategy of content analysis, analyzing sentence-by-sentence related to the terms and following the steps of reduction, display, conclusion and double verification in isolation (double blind) (FLICK, 2009), producing a classification of the articles in seven categories. The categories were: transparency, participation, innovation, reuse, accountability, collaboration and added value.

In the sixth phase, the terms covered in the articles were identified using the Word Frequency functionality of NVIVO 11. The most frequent words were validated through the comparison with the results of the research by Hossain et al. (2016) and Attard et al. (2015). For each item addressed an a priori axial category was assigned (GIBBS, 2008) with various terms of similar meaning for the search in the next stage.

In the seventh phase searches were conducted in the articles content, through the MAXQDA 12 software search tool, using the keywords of each axial category of focus. Through excerpts obtained by MAXQDA, the articles were reanalyzed and the respective categories of items covered by the article were designated to them.

\section{Analyses and Results}

As illustrated in Figure 1, there were no studies previous to 2010, although a starting 
year was not established in the search criteria described in Table 1. However, the results increase significantly in subsequent years. This demonstrates the scientific interest in the theme, which grows concomitantly with the number of initiatives of open data in the world.

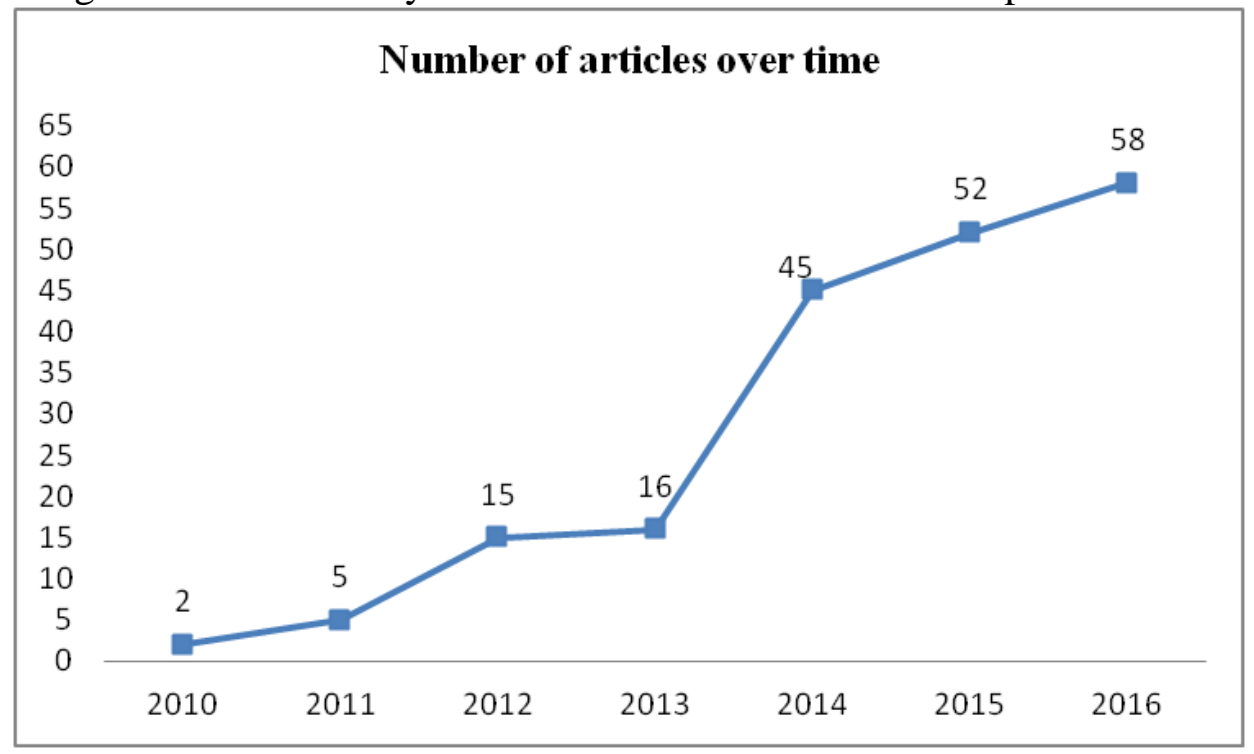

Figure 1-Publications by year

Table 2 identifies the journals with more than two articles published. The journal Government Information Quarterly stands out from the others, contributing with 29 articles, equivalent to $16 \%$ of publications.

\begin{tabular}{|l|c|}
\hline \multicolumn{1}{|c|}{ Main Journals } & Number of studies \\
\hline Government Information Quarterly & 29 \\
\hline Information Polity & 10 \\
\hline Social Science Computer Review & 7 \\
\hline Journal of Theoretical and Applied Electronic Commerce Research & 6 \\
\hline IEEE Intelligent Systems & 5 \\
\hline Transforming Government: People, Process and Policy & 5 \\
\hline Journal of Organizational Computing and Electronic Commerce & 4 \\
\hline Policy and Internet & 4 \\
\hline Procedia - Social and Behavioral Sciences & 4 \\
\hline Procedia Computer Science & 4 \\
\hline Semantic Web & 4 \\
\hline Records Management Journal & 3 \\
\hline Australian Economic Review & 2 \\
\hline Computers in Industry & 2 \\
\hline Hitachi Review & 2 \\
\hline IEEE Internet Computing & 2 \\
\hline Journal of E-Learning and Knowledge Society & 2 \\
\hline Journal of the American Society for Information Science and Technology & 2 \\
\hline Journal of the Knowledge Economy & 2 \\
\hline Journal of Web Semantics & 2 \\
\hline Review of Policy Research & 2 \\
\hline Scientific Papers of the University of Pardubice & 2 \\
\hline Statistical Journal of the IAOS & 2 \\
\hline
\end{tabular}

Table 2 - Journals that published more than two papers on the subject

Figure 2 presents the twelve authors with three or more published articles, according 
to the selection criteria of this study.

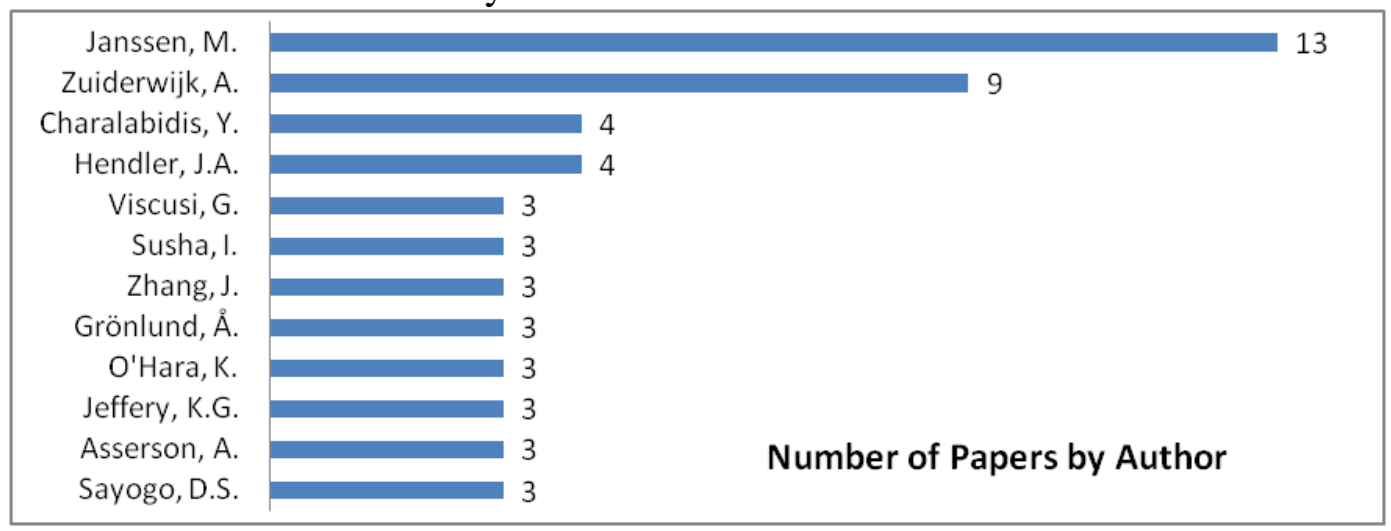

Figure 2 -Authors that published three or more papers on the subject

Table 3 shows the twenty most cited articles, along with their respective number of citations, as indicated by the databases used in this research.

\begin{tabular}{|c|c|}
\hline Title Studies & 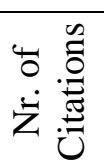 \\
\hline $\begin{array}{l}\text { Benefits, Adoption Barriers and Myths of Open Data and Open Government (JANSSEN et } \\
\text { al., 2012). }\end{array}$ & 153 \\
\hline $\begin{array}{l}\text { An Open Government Maturity Model for social media-based public engagement (LEE and } \\
\text { KWAK, 2012). }\end{array}$ & 111 \\
\hline $\begin{array}{l}\text { Open data policies, their implementation and impact: A framework for comparison } \\
\text { (ZUIDERWIJK and JANSSEN, 2014). }\end{array}$ & 73 \\
\hline $\begin{array}{l}\text { The influence of the PSI directive on Open Government Data: An overview of recent } \\
\text { developments (JANSSEN, 2011). }\end{array}$ & 71 \\
\hline Linked Open Government Data: Lessons from data.gov.uk (SHADBOLT et al., 2012). & 65 \\
\hline TWC LOGD: A portal for linked Open Government Data ecosystems (DING et al., 2011). & 49 \\
\hline A Smart City Initiative: The Case of Barcelona (BAKICI et al., 2013). & 39 \\
\hline $\begin{array}{l}\text { A classification scheme for Open Government Data: Towards linking decentralized data } \\
\text { (KALAMPOKIS et al., 2011) }\end{array}$ & 36 \\
\hline $\begin{array}{l}\text { XBRL and Open Data for global financial ecosystems: A linked data approach (O'RIAIN et } \\
\text { al., 2012). }\end{array}$ & 34 \\
\hline $\begin{array}{l}\text { A promising phenomenon of Open Data: A case study of the Chicago open data project } \\
\text { (KASSEN, 2013). }\end{array}$ & 33 \\
\hline Benchmarking Open Government: An open data perspective (VELJKOVIĆ et al., 2014). & 28 \\
\hline $\begin{array}{l}\text { Towards a global participatory platform: Democratising open data, complexity science and } \\
\text { collective intelligence (BUCKINGHAM SHUM et al., 2012). }\end{array}$ & 27 \\
\hline $\begin{array}{l}\text { On the barriers for local government releasing open data (CONRADIE and CHOENNI, } \\
\text { 2014). }\end{array}$ & 26 \\
\hline $\begin{array}{l}\text { Accidental, open and everywhere: Emerging data sources for the understanding of cities } \\
\text { (ARRIBAS-BEL, 2014). }\end{array}$ & 26 \\
\hline US government linked open data: Semantic.data.gov (HENDLER et al., 2012). & 26 \\
\hline $\begin{array}{l}\text { Infomediary Business Models for Connecting Open Data Providers and Users (JANSSEN and } \\
\text { ZUIDERWIJK, 2014). }\end{array}$ & 21 \\
\hline Linked data in government (SHADBOLT and O'HARA, 2013). & 20 \\
\hline Industrial ecology 2.0 (DAVIS et al., 2010). & 20 \\
\hline $\begin{array}{l}\text { Exploring the determinants of scientific data sharing: Understanding the motivation to publish } \\
\text { research data (SAYOGO and PARDO, 2013). }\end{array}$ & 19 \\
\hline
\end{tabular}


Big data, Open Government and e-government: Issues, policies and recommendations (BERTOT et al., 2014).

\section{Table 3 - The 20 most cited studies}

Table 4 presents the most clearly definitions of OGD, among the 193 articles, in a chronological order, and highlights some of the terms used in these definitions. These terms originated the categories. Notably, the authors point out that the governments, motivated by the need for transparency, become data available, expecting that these data gain value through their reuse in services created by companies and citizens, generating innovation for society.

Indispensable in the development of public policies and the provision of services, valuable to citizens, organizations and public companies, decision-making and in the creation of innovative products and services (JANSSEN, 2011).

The last years have seen the emergence of a "Data Web", fuelled by initiatives of Open Government transparency, which has made a significant amount of public sector information freely available for use and redistribution without restrictions (O'RIAIN et al. 2012). Open government data is an important component in supporting data innovation, an approach in which companies analyze data to obtain information in respect to their area of activity, stakeholders and competitors, or on the development of new service opportunities (O'RIAIN et al., 2012).

Public sector open data connects useful information for citizens and businesses in their dealings with the public sector (GALIOTOU and FRAGKOU, 2013).

Open Government data initiatives are based on transparency, participation and collaboration for the strengthening of democracy. Through these three pillars, the publication of government data sets not only has the potential to improve accountability and curb corruption, but to also to affect everyone involved in various ways (ATTARD et al., 2015).

Transparency improves public accountability, citizen participation, and collaborative cross-sector partnerships (LINDERS, 2013).

The formulation of evidence-based policies, strategic planning, performance monitoring and resultsbased management requires extensive knowledge on the current conditions of a country and the impact of the projects and demands huge amounts of data from a wide variety of sources on every topic. Open data platforms can help make public these essential components of knowledge. The powerful advantage of an open data approach is that it also makes the data findable, reusable, accessible, interoperable and machine-readable, dramatically improving the efficiency of analyses and insights (LINDERS, 2013).

When opening their data government agencies have the potential to promote transparency, increase citizen participation and stimulate innovation. In addition, the open data initiatives can help citizens learn about government activities improve government accountability and allow citizens to participate in the political process. Open data initiatives can also provide the data that independent parties need to assess the quality of the policy targets in government decision-making (WHITMORE, 2014).

It refers to data produced or commissioned by government or government-controlled entities, which can be used freely, reused and redistributed by anyone. The nucleus of the OGD movement establishes the proactive disclosure of raw unstructured data, aiming firstly at innovation and economic growth by exploiting the provided data for the production of new value-added products, and secondly at the provision of accountability and transparency through access to data that has political value (YANNOUKAKOU and ARAKA, 2014).

They provide useful information to citizens and companies for their transactions with the public sector, available to anyone to analyze and reuse, it is organized and published chaotically and its exploitation in its current state remains a difficult task. This will be simplified only if the public sector data is transformed into connected Open Data, in order to meet the minimum requirements for the interconnection and reuse of the data. The term "connected data" refers to data published on the web in a form that is machine readable and linked to other sets of external data and can in turn be connected to from external data sets (FRAGKOU et al., 2014). 
Data of public interest that is available without any restrictions and that can be easily found and accessed. This may include transport data, spatial data, meteorological information, reports, images and other information of public interest (VELJKOVIĆ et al., 2014).

It is available for reasons of transparency and to promote a market of added value services. Starting with the desire of governments to appear more transparent, it has become a trend in Western countries. In fact, the principal motivation is that by making available the data sets collected by government departments, with taxpayer funding, commercial companies will be encouraged to provide commercial services using this open data and add value to the end user (JEFFERY et al., 2014).

Available data sets collected by government departments with funding from the taxpayer. From which private companies are encouraged to provide commercial services that use this open data, adding value to the end user (JEFFERY and ASSERSON, 2014).

Free to use, reuse and redistribute, sharing the same license. In this context, the movement Open Government Data makes a great effort to spread this vision in public bodies around the world, with the objective of making information available to the public and of the creation of economies of scale due to data reuse and the creation, with the data, of more valued and enriched services (ALVAREZ-RODRÍGUEZ et al., 2014).

It is the information policy that provides a particular structure in which the data sets that are produced by public institutions are destined for use by third parties. The "non-personal" data produced by public bodies should be open for all to be reused, free of charge and without discrimination (BATES, 2014).

To meet one of the main objectives of Open Government: to promote transparency through the publication of government data and, thus, allow accountability of public officials and the reuse of the data disclosed with social or economic value (LOURENÇO, 2015).

In recent years, a series of open data movements have emerged around the world, with transparency and reuse of data as two of the principal objectives. The Open Government Data Portals, resulting from such movements, provide a means for citizens and stakeholders to obtain government information on the locality or country in question (ATTARD et al., 2015).

\section{Table 4 - Sample definitions of the concept of Open Government Data}

Table 4 highlights some dimensions of OGD, which were identified through content analysis, during the fifth phase of analysis of articles. The terms "reuse" and "add value" have arisen more emphatically in more recent definitions about OGD and the term "transparency" is almost a constant among definitions.

\subsection{Open Government Data Dimensions}

The dimensions can be analyzed by the goal or benefit biases of OGD, at any rate they are interconnected and encompassed by diverse approaches, for example, transparency can be considered one of the benefits of OGD, as described in Table 4.

The identified dimensions are shown in Figure 3 along with the number of articles that addressed them. Each analyzed article can be counted in more than one dimension, depending on its content. The list of 20 most popular articles that discuss each dimension is contained in Appendix A. 


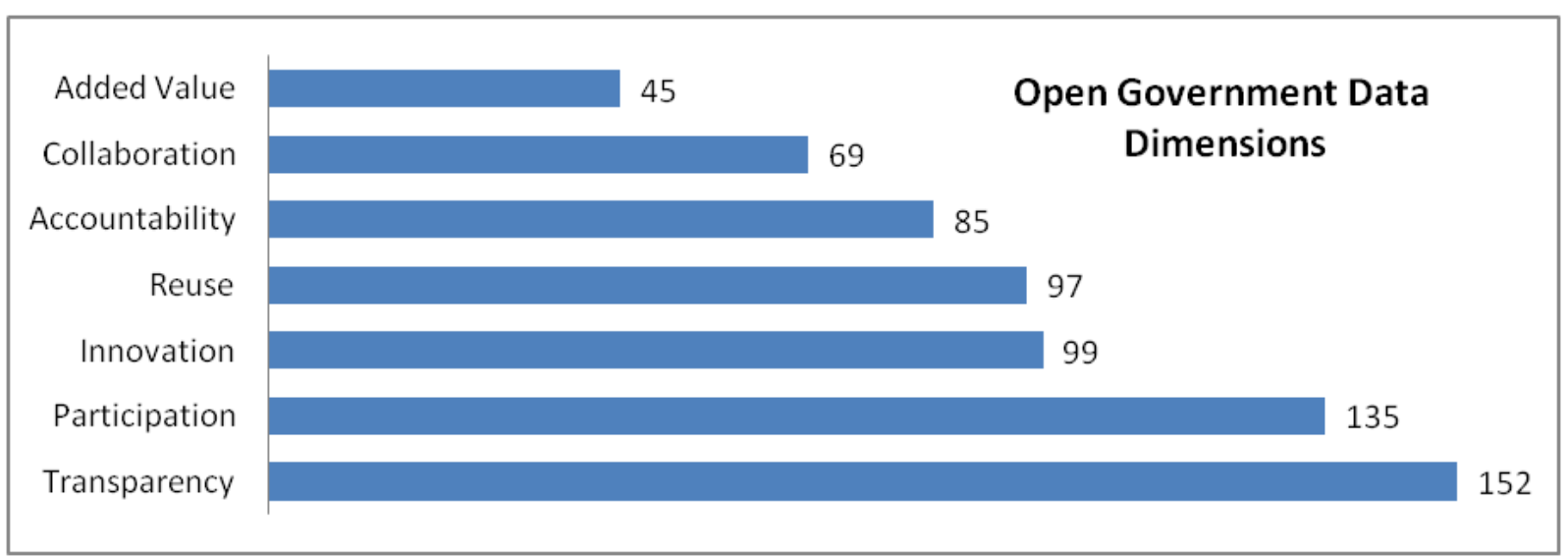

Figure 3 - Dimensions and Number of Studies

Transparency is considered the precursor of accountability (GARCIA and SORIANO MALDONADO, 2012; AL-JAMAL and ABU-SHANAB, 2016) and is closely connected to a reduction in levels of corruption, through the accountability of public officials (MURILLO, 2015), even though the relationship between them is not complete (WORTHY, 2015). However, the lack of data quality is a risk to transparency (KOUSSOURIS et al., 2015), as well as the lack of policies that ensure the continued availability of updated data (NUGROHO et al., 2015; SOLAR et al., 2014; LEONTIEVA et al., 2015). The research of Meijer (2015) stands out in the transparency approach, by addressing its various levels, namely: a) legal fundaments of transparency (1801); b) transparency embedded in the polity (1800s, 1900s); c) detailed transparency legislation (1980s) and e) transparency embedded in individual government-society relations (1990s, 2000s). The Dawes (2010) research is another article to be highlighted, because deals with important properties of transparency, such as stewardship and usefulness.

According to Barry and Bannister (2014), in the UK the full objective of accountability through transparency was not reached, due to the lack of citizen participation, caused by lack of understanding and trust in the data. However, the participation is linked primarily to adequate disclosure, through advertising or public notice, thus the citizens are aware of the availability of open data and how this data can be used (KHAYYAT and BANNISTER, 2015); consecutively, that depends on the data quality (AL-JAMAL and ABUSHANAB, 2016; SÁEZ MARTÍN et al., 2016; WANG and LO, 2016), on the trust in government and on the understanding of the available data (WIRTZ et al., 2016; AL-JAMAL and ABU-SHANAB, 2016). In this sense, the research of Al-Jamal and Abu-Shanab (2016) indicated that the information quality is a determinant in government data use intention.

Paradoxically, the improvement of quality can be achieved by increase participation and inherent feedback on the publications (ATTARD et al. 2015); additionally it can be obtained by adding services and applications that depend on the data and consequently generate pressures for higher quality (ZELETI et al., 2016). Another form of qualification that was identified is the co-creation of data sets, with the participation of governmental publishers and future users of the data (ZELETI et al., 2016).

Regarding innovation, OGD aims primarily at innovation and economic growth, exploring the data to produce new products with added value (YANNOUKAKOU and ARAKA, 2014). OGD can be thought of as an innovation to help government agencies achieve the principles of Open Government, including transparency, participation and collaboration (YANG and WU, 2016). According to Lakomaa and Kallberg (2013), Open Data is essential for innovation in applications and information services, influencing the innovative process in many ways. Conversely, the absence of the Open Data retards the 
innovative process and, in these circumstances, impedes the beginning of business innovation (LAKOMAA and KALLBERG, 2013).

Gonzalez-Zapata and Heeks (2015) pointed out that OGD is an innovation from the technological perspective, with changes performed by technical professionals in ICT and the involvement and availability of new design formats, processes and data standards. OGD directly supports data innovation in which raw government data is analyzed by companies and used to better inform stakeholders about their business situations or the development of new service opportunities (O'RIAIN et al. 2012), highlighting the importance of promoting public innovation, and stimulating the creative use of the data with awards and recognition (KHAYYAT and BANNISTER, 2015). For Hellberg and Hedström (2015), many of the policies, that until now addressed the public data reuse, consider OGD as an engine for innovation. New technologies have emerged from the web, making data exchange and data reuse a reality (CURTIN, 2010). The main task of governments and authorities involved is not only to open their public data, but also to encourage users to reuse it. The idea is not to provide new or improved services to citizens, but to put at their disposal tools to evaluate the work of the government and also to produce services to substitute or complement those offered by public sector bodies (MARAMIERI, 2014). Through government portals, the reuse of information held by government agencies encourages the generation of qualified services, reduces workload and redundant procedures, and ensures unrestricted access for citizens (YANNOUKAKOU and ARAKA, 2014).

Veljković et al. (2014) point out that collaboration is aimed at more responsive decision-making based on collaborative work and feedback information, and identifies different types of government collaboration, namely G2G (government to government), G2B (government to business) and G2C (government to citizens). The publication of OGD can stimulate the cooperation among various stakeholders, facilitating its use (ZUIDERWIJK et al. 2014). Sieber and Johnson (2015) argue that a participatory model presents open data as a formalized channel between citizen and government, where the contributions of citizens are integrated into decision-making, with the government focused on meeting data demands, as well as future data. In the Open Government Maturity Model (OGMM), proposed by Lee and Kwak (2012), government agencies reach collaboration maturity (corresponding to the fourth level out of five) when they promote collaboration among government agencies and public and private sector, and when public involvement in tasks or complex projects aims to generate specific results. Zuiderwijk and Janssen (2014) point out possible reasons for the lack of collaboration in organizations, such as: the operability at different government levels, which are assigned different responsibilities and have different data types; differences between organizations regarding mission types; and motivations behind the development of policies and policy objectives.

In terms of added value, Zeleti et al. (2016) address the business model and modes of exploring the rising value of open data. Al-Debei and Avison (2010) derived a unified business model based on a comprehensive literature review. They argue that the model provides an abstract, but holistic vision, and that the fundamental dimensions are based on value. There are four relevant structural aspects of the business model: a) Value proposition the business logic to create value for customers by offering products and services to specific segments; b) Value architecture - an architecture for technological and organizational infrastructure used in the provision of goods and services; c) Value network - collaboration and coordination with other organizations; and d) Value financing - costing, pricing and revenue sharing associated with sustaining and enhancing value creation. The value to be added can be economic, social, governmental or political (GONZALEZ-ZAPATA and HEEKS, 2015). Governmental value can be a technological innovation within government 
data systems. Public or social value can be improvements in public services through greater efficiency and effectiveness of data management. The governance value can be greater transparency, accountability, participation and empowerment. Economic value, in turn, can be through new products, services, revenues, profits and jobs.

In this regard, the article of Janssen and Zuiderwijk (2014) compares different modes of use of open data. They identified six types of business model, namely: single-use applications, interactive applications, aggregators of information, comparison of models, open data repositories and service platforms. The cases investigated by the authors differ in their levels of access to raw data and in how they stimulate dialogue among the different actors involved in the publication and use of open data. The distinction between different types of open data users was considered critical in explaining the different business models.

All the dimensions quoted are addressed in the articles by different approaches, which produce new perspectives. To illustrate these perspectives, ten principal usually addressed items were identified, which are listed below.

\subsection{Open Government Data Approaches}

After establishing the dimensions covered by each article, the articles were analyzed and assigned to categories according to the terms mentioned by them. Following the previously described methodology, 10 categories were defined. Papers were grouped in categories according to the following criteria:

a) Policy category is formed by the terms that addressed policy and politics;

b) Benefit category is formed by the terms benefit, contribution and advantage;

c) For Risks, we used the terms risk, jeopardize, hazard and danger;

d) For Barrier, we used barrier, obstacle, hurdle, impediment and restriction;

e) In the Motivation category we used incentive, motivation and stimulus.

In the other categories, the name of the category was used as a search term. Two researches reviewed (double blind) each text extract that was addressing each term.

Figure 4 shows the categories of items covered and the number of articles mentioning them. The list of 20 most popular articles that refers the terms is shown in the Appendix A.

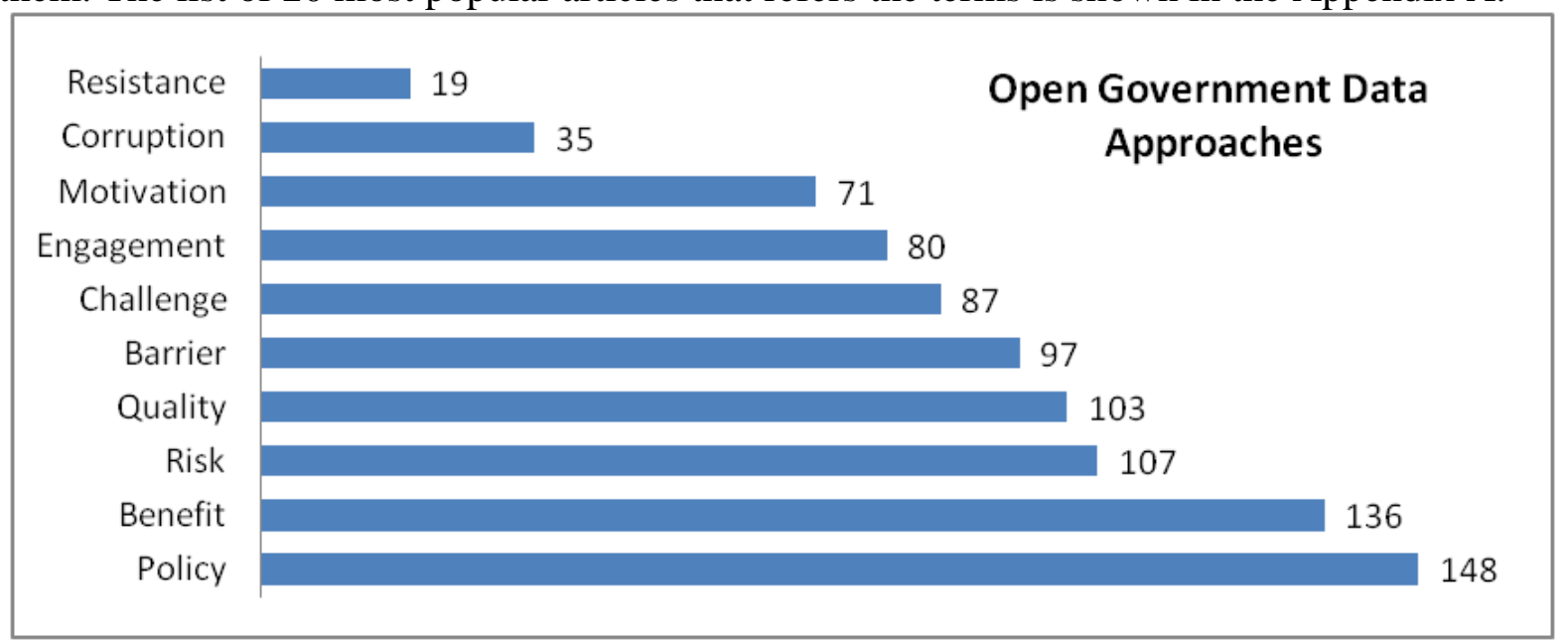

Figure 4-Approaches and Number of Studies

Several of the approaches showed in Figure 4 are linked with dimensions showed before (item 3.2), and some others may have emphasized other aspects, for example, risk and related terms. The articles approaching risk addressed issues such as information security risk, adulteration of published data and citizens' loss of privacy risk by inadvertently publishing confidential data (LEE and KWAK, 2012; YANG and WU, 2016). These risks may be 
considered barriers because, according to Wirtz et al. (2016), the high-risk aversion of public organizations employees is the main source of resistance to the publication of public data. As a consequence, risks perception becomes a barrier to OGD.

According to Zuiderwijk and Janssen (2014), the willingness of a government agency to become truly open and publish data is based on the analysis of the potential risks of becoming open. Janssen et al. (2012) suggest that cultural changes are necessary, since risk aversion culture leads to reluctance to change and generates a tendency to not to open the data. For Yang and Wu (2016) the existence of a government agency, designated as a coordinator to other agencies, can help to obtain facilities and concerns about data misuse could be attenuated.

Additionally, other kinds of risks are mentioned among the analyzed articles. Vetro et al. (2016) claim that data quality jeopardizes citizens' participation, since practitioners evidences demonstrate that disclosure of data, without adequate quality control, may compromise data reuse and adversely affect civic participation. Furthermore, there are risks related to information misuse and misunderstanding because of the absence of correct explanation and contextualization (LÉVEILLÉ and TIMMS; 2015). In this context, Attard et al. (2015) suggest that more meaningful data formats that describe the meaning of the data can help users to mitigate the risk of data ambiguity and misinterpretation.

Among the articles that discuss the term challenge, it is possible to highlight the article from Lee and Kwak (2012), which lists several of challenges according to the level of maturity of government agencies that publish data. In general, other articles mention challenges overcoming OGD's barriers, which in most cases include poor data quality, low social participation, civil servant culture, costs of combining data sources and data publication, lack of policies and regulations to promote data publication and regulations to data publication continuity and limited support for the data consumer.

Policy is one of the topics most discussed, tackled as a way to make OGD publications feasible and as a mechanism to ensure the continuity of the data already published. On the other hand, the benefits are addressed, in most articles, in a conceptual way, as potentials gains to society and government.

It is particularly noticeable that the themes resistance and corruption can be better explored. Most articles that approach corruption address the potential of open data in fighting corruption and discuss indexes used in the perception of corruption. It is an OGD important service to help the fight against corruption, even if the contribution is indirect - open data can be analyzed by citizens, so they can denunciate irregularities on public administration that can call attention to corruption. It is a hard endeavor where citizens' mobilization is mandatory and the results can only be perceived in the long-run.

Overall, OGD publications have tripled in the last three years and are centered on Government Information Quarterly journal, with emphasis to authors Janssen M. and Zuiderwijk A., who publish the most on this subject. It is possible to observe that OGD concept changed over the years from a perspective more focused in transparency to a perspective of value added. The dimensions transparency and participation are more easily found in the papers from the early years, while dimensions accountability, and concerns about participations appeared in publications from more recent years. The same occurs with approaches, which changed from barrier to quality and policy along the years. These changes show not just the development of concepts but also the evolution of the Open Data and Open Government Data domain.

\section{Final Remarks}

This article provided an overview of the dimensions of Open Data in the government 
area, performed through a systematic review of the literature. It was found that the research area of Open Government Data (OGD) has grown substantially in recent years. The increasing importance of this subject to a more open and transparent government justifies this study, which indicates the status quo and provides insights to future researches by identifying approaches and dimensions that can be explored in the future. We suggest that approaches like corruption and resistance might be better explored not just because they are in small numbers but especially because they are important to increase transparency and citizens' participation.

In terms of practical contributions, this article helps the various agents of the OGD ecosystem to identify more clearly what article deals with each subject. In relation to policymakers, it emphasizes the importance of politics in the OGD theme.

The research on OGD was classified into seven dimensions and under ten different themes. The results showed that resistance and corruption are the themes least addressed, and that added value is a dimension to be further explored in future research. Moreover, this study point to significant differences between the dimensions and terms discussed in articles about OGD, for example, the Transparency dimension with 152 articles (79\%), in contrast to Added Value with 45 articles (23\%), and Collaboration with 69 articles (36\%). These differences were also found in the themes addressed, for example, Policy in 148 articles (77\%), against Resistance with only 19 articles (10\%) or Corruption addressed in only 35 articles (18\%).

Thus, it is apparent that the OGD research area reflects the degree of maturity of Open Government Data initiatives, as evidenced in the Open Data Barometer Report (Davies et al., 2015). For example, among the 20 most cited articles, 11 were collected in USA, 10 in UK, 5 in The Netherlands and 2 articles in Canada, which correspond respectively to the $2^{\text {nd }}, 1^{\text {st }}, 7^{\text {th }}$, and $4^{\text {th }}$ place in The Open Data Barometer Report of 2015 (OPENDATABAROMETER, 2016).

Despite the large discrepancy in maturity levels among countries, a few initiatives, on a global level, achieved an effective increase of economic or social value from the available open data, even though it is not yet working on the mitigation of corruption. On the other hand, the OGD initiatives mostly are still at the stage of establishing national and regional policies to ensure their implementation and continuity (DAVIES et al., 2015). This is clearly reflected in the widely discussed policy theme.

This study has some limitations, since only articles published in journals were analyzed. Moreover, the research was restricted to the four main databases in Information System and Electronic Government area. New databases can be considered in future researches.

Considering the period of the selected articles, it is consistent that even countries now considered fully mature in relation to the open data initiatives have addressed issues relating to policy in articles from previous years, when they were still implementing their initiatives. In short, new scientific papers will direct their focus on issues such as added value and corruption concurrently with the maturation of global OGD initiatives,

Future research could address aspects that added public value to open government data, exploring the successes in co-creation processes, which involves society and government, during the choice of data to be published and also on the data governance process. 


\section{REFERENCES}

AL-DEBEI, M. M.; AVISON, D. Developing a unified framework of the business model concept. European Journal of Information Systems, v. 19, n. 3, p. 359-376, 2010.

AL-JAMAL, M.; ABU-SHANAB, E. The influence of open government on e-government website: the case of Jordan. International Journal of Electronic Governance, v. 8, n. 2, p. 159-179, 2016.

ALVAREZ-RODRÍGUEZ, J. M.; LABRA-GAYO, J. E.; DE PABLOS, P. O. New trends on e-Procurement applying semantic technologies: Current status and future challenges. Computers in Industry, v. 65, n. 5, p. 800-820, 2014.

ANDERSEN, T. B. E-Government as an anti-corruption strategy. Information Economics and Policy, v. 21, n. 3, p. 201-210, 2009.

ARRIBAS-BEL, D. Accidental, open and everywhere: Emerging data sources for the understanding of cities. Applied Geography, v. 49, p. 45-53, 2014.

ATTARD, J.; ORLANDI, F.; SCERRI, S.; AUER, S. A systematic review of open government data initiatives. Government Information Quarterly, v. 32, n. 4, p. 399-418, 2015.

BAKICI, T.; ALMIRALL, E.; WAREHAM, J. A Smart City Initiative: The Case of Barcelona. Journal of the Knowledge Economy, v. 4, n. 2, p. 135-148, 2013.

BARRY, E.; BANNISTER, F. Barriers to open data release: A view from the top. Information Polity, v. 19, p. 129-152, 2014.

BATES, J. The strategic importance of information policy for the contemporary neoliberal state: The case of Open Government Data in the United Kingdom. Government Information Quarterly, v. 31, n. 3, p. 388-395, 2014.

BAUMEISTER, R. F.; LEARY, M. R. Writing narrative literature reviews. Review of General Psychology, v. 1, n. 3, p. 311, 1997.

BEM, D. J. Writing a review article for Psychological Bulletin. Psychological Bulletin, v. 118, n. 2, p. 172, 1995.

BERTOT, J. C. et al. Big data, open government and e-government: Issues, policies and recommendations. Information Polity, v. 19, n. 1-2, p. 5-16, 2014.

BUCKINGHAM SHUM, S. et al. Towards a global participatory platform: Democratising open data, complexity science and collective intelligence. European Physical Journal: Special Topics, v. 214, n. 1, p. 109-152, 2012.

CONRADIE, P.; CHOENNI, S. On the barriers for local government releasing open data. Government Information Quarterly, v. 31, p. S10-S17, 2014.

COOPER, H.; HEDGES, L. V.; VALENTINE, J. C. The handbook of research synthesis and meta-analysis. Russell Sage Foundation, 2009.

CURTIN, G. G. Free the data!: E-governance for megaregions. Public Works Management \& Policy, v. 14, n. 3, p. 307-326, 2010.

DAVIES, T. Open Data Barometer 2013 Global Report. World Wide Web Foundation and Open Data Institute. 2013. URL: http://www.opendataresearch.org/dl/odb2013/ Open-DataBarometer-2013-Global-Report.pdf (visited on 14 jan. 2016). 
DAVIES, T.; SHARIF, R. M.; ALONSO, J. M. Open Data Barometer Global Report. World Wide Web Foundation, 2015.

DAVIS, C.; NIKOLIC, I.; DIJKEMA, G. P. J. Industrial ecology 2.0. Journal of Industrial Ecology, v. 14, n. 5, p. 707-726, 2010.

DAWES, S. S. Stewardship and usefulness: Policy principles for information-based transparency. Government Information Quarterly, v. 27, n. 4, p. 377-383, 2010.

DING, L. et al. TWC LOGD: A portal for linked open government data ecosystems. Journal of Web Semantics, v. 9, n. 3, p. 325-333, 2011.

FLICK, U. Introdução a Pesquisa Qualitativa. 3 ed. Porto Alegre:Artmed, 2009.

FRAGKOU, P.; GALIOTOU, E.; MATSAKAS, M. Enriching the e-GIF Ontology for an Improved Application of Linking Data Technologies to Greek Open Government Data. Procedia - Social and Behavioral Sciences, v. 147, p. 167-174, 2014.

GALIOTOU, E.; FRAGKOU, P. Applying Linked Data Technologies to Greek Open Government Data: A Case Study. Procedia - Social and Behavioral Sciences, v. 73, p. 479486, 2013.

GARCIA, E. G.; SORIANO MALDONADO, S. L. Reuse of Public Sector Information in Spain: A solid foundation for a promising future. Textos Universitaris de Biblioteconomia I Documentació, v. 29, 2012.

GIBBS, G. R. Analysing qualitative data. Sage, 2008.

GONZALEZ-ZAPATA, F.; HEEKS, R. The multiple meanings of open government data: Understanding different stakeholders and their perspectives. Government Information Quarterly, v. 32, n. 4, p. 441-452, 2015.

HARRISON, T. M. et al. Open government and e-government: Democratic challenges from a public value perspective, Information Polity, v. 17, p. 83-97, 2012.

HELLBERG, A. S.; HEDSTRÖM, K. The story of the sixth myth of open data and open government. Transforming Government: People, Process and Policy, v. 9, n. 1, p. 35-51, 2015.

HENDLER, J.; HOLM, J.; MUSIALEK, C.; THOMAS, G. US government linked open data: Semantic.data.gov. IEEE Intelligent Systems, v. 27, n. 3, p. 25-31, 2012.

HOSSAIN, M. A.; DWIVEDI, Y. K.; RANA, N. P. State-of-the-art in open data research: Insights from existing literature and a research agenda. Journal of organizational computing and electronic commerce, v. 26, n. 1-2, p. 14-40, 2016.

JANSSEN, K. The influence of the PSI directive on open government data: An overview of recent developments. Government Information Quarterly, v. 28, n. 4, p. 446-456, 2011.

JANSSEN, M.; CHARALABIDIS, Y.; ZUIDERWIJK, A. Benefits, Adoption Barriers and Myths of Open Data and Open Government. Information Systems Management, v. 29, n. 4, p. 258-268, set. 2012.

JANSSEN, M.; ZUIDERWIJK, A. Infomediary Business Models for Connecting Open Data Providers and Users. Social Science Computer Review, v. 32, n. 3, 2014.

JEFFERY, K. G.; ASSERSON, A. Data Intensive Science: Shades of Grey. Procedia Computer Science, v. 33, p. 223-230, 2014. 
JEFFERY, K. G. et al. From Open Data to Data-intensive Science through CERIF. Procedia Computer Science, v. 33, p. 191-198, 2014.

KALAMPOKIS, E.; EFTHIMIOS, T.; KONSTANTINOS, T. A classification scheme for open government data: towards linking decentralised data. International Journal of Web Engineering and Technology, v. 6, n. 3, p. 266-285, 2011.

KASSEN, M. A promising phenomenon of open data: A case study of the Chicago open data project. Government Information Quarterly, v. 30, n. 4, p. 508-513, 2013.

KHAYYAT, M.; BANNISTER, F. Open data licensing: More than meets the eye. Information Polity, v. 20, n. 4, p. 231-252, 2015.

KOUSSOURIS, S. et al. Accelerating Policy Making 2.0: Innovation directions and research perspectives as distilled from four standout cases. Government Information Quarterly, v. 32, n. 2, p. 142-153, 2015.

LAKOMAA, E.; KALLBERG, J. Open data as a foundation for innovation: The enabling effect of free public sector information for entrepreneurs. IEEE Access, v. 1, p. 558-563, 2013.

LEE, G.; KWAK, Y. H. An Open Government Maturity Model for social media-based public engagement. Government Information Quarterly, v. 29, n. 4, p. 492-503, 2012.

LEONTIEVA, L. S.; KHALILOVA, T. V., GAYNULLINA, L. F., KHALILOV, A. I. Socialcommunicative innovations in anti-corruption activities (Regional aspect). Asian Social Science, v. 11, n. 7, p. 387, 2015.

LÉVEILLÉ, V.; TIMMS, K. Through a Records Management Lens: Creating a Framework for Trust in Open Government and Open Government Information/Les objectifs visés par les systèmes de gestion documentaires: La mise en place d'un cadre de confiance et de la transparence de l'information dans un gouvernement ouvert. Canadian Journal of Information and Library Science, v. 39, n. 2, p. 154-190, 2015.

LINDERS, D. Towards open development: Leveraging open data to improve the planning and coordination of international aid. Government Information Quarterly, v. 30, n. 4, p. 426434, 2013.

LOURENÇO, R. P. An analysis of open government portals: A perspective of transparency for accountability. Government Information Quarterly, v. 32, n. 3, p. 323-332, 2015.

MARAMIERI, J. Open government data: A citizen's right or a concession of public authorities? Journal of E-Learning and Knowledge Society, v. 10, n. 2, p. 11-22, 2014.

MEIJER, A. Government Transparency in Historical Perspective: From the Ancient Regime to Open Data in The Netherlands. International Journal of Public Administration, v. 38, n. March, p. 189-199, 2015.

MURILLO, M. J. Evaluating the role of online data availability: The case of economic and institutional transparency in sixteen Latin American nations. International Political Science Review, v. 36, n. 1, p. 42-59, 2015.

NUGROHO, R. P.; ZUIDERWIJK, A.; JANSSEN, M.; de JONG, M. A comparison of national open data policies: lessons learned. Transforming Government: People, Process and Policy, v. 9, n. 3, p. 286-308, 2015. 
OGD. Open Government Data. Eight principles of open government data. 2016. URL: https://opengovdata.org (visited on 03/02/ 2016).

OPENDATABAROMETER, A global measure of how governments are publishing and using open data for accountability, innovation and social impact. 2016. URL: http://opendatabarometer.org/?_year=2015\&indicator=ODB (visited on 11/12/2016).

O'RIAIN, S.; CURRY, E.; HARTH, A. XBRL and open data for global financial ecosystems: A linked data approach. International Journal of Accounting Information Systems, v. 13, n. 2, p. 141-162, 2012.

SÁEZ MARTÍN, A.; ROSARIO, A. H.; PÉREZ, M. D. C. C. An international analysis of the quality of open government data portals. Social Science Computer Review, v. 34, n. 3, p. 298-311, 2016.

SAYOGO, D. S.; PARDO, T. A. Exploring the determinants of scientific data sharing: Understanding the motivation to publish research data. Government Information Quarterly, v. 30, n. SUPPL. 1, p. S19-S31, 2013.

Science Direct. URL: http://www.sciencedirect.com. 2016 (visited on 11/08/2016).

SCHOLL, H. J. Five trends that matter: Challenges to 21 st century electronic government. Information Polity, v. 17, p. 317-327, 2012.

Scopus. URL: http://www.scopus.com. 2016 (visited on 11/08/2016).

SHADBOLT, N.; O'HARA, K. Linked data in government. IEEE Internet Computing, n. July/August 2013, 2013.

SHADBOLT, N. et al. Linked open government data: Lessons from data.gov.uk. IEEE Intelligent Systems, v. 27, n. 3, p. 16-24, 2012.

SIEBER, R. E.; JOHNSON, P. A. Civic open data at a crossroads: Dominant models and current challenges. Government Information Quarterly, v. 32, n. 3, p. 308-315, 2015.

SOLAR, M.; DANIELS, F.; LÓPEZ, R.; MEIJUEIRO, L. A model to guide the open government data implementation in public agencies. Journal of Universal Computer Science, v. 20, n. 11, p. 1564-1582, 2014.

STAMATI, T.; PAPADOPOULOS, T.; ANAGNOSTOPOULOS, D. Social media for openness and accountability in the public sector: Cases in the Greek context. Government Information Quarterly, v. 32, n. 1, p. 12-29, 2015

UBALDI, B. Open government data: Towards empirical analysis of open government data initiatives. OECD Working Papers on Public Governance, n. 22, p. 0_1, 2013.

VELJKOVIĆ, N.; BOGDANOVIĆ-DINIĆ, S.; STOIMENOV, L. Benchmarking open government: An open data perspective. Government Information Quarterly, v. 31, n. 2, p. 278-290, 2014.

VETRÒ, A. et al. Open data quality measurement framework: Definition and application to Open Government Data. Government Information Quarterly, v. 33, n. 2, p. 325-337, 2016.

WANG, H. J.; LO, J. Adoption of open government data among government agencies. Government Information Quarterly, v. 33, n. 1, p. 80-88, 2016.

Web of Knowledge. URL: http://apps.webofknowledge.com (visited on 11/08/2016).

WHITMORE, A. Using open government data to predict war: A case study of data and 
systems challenges. Government Information Quarterly, v. 31, n. 4, p. 622-630, 2014.

WIRTZ, B. W.; PIEHLER, R.; THOMAS, M. J.; DAISER, P. Resistance of Public Personnel to Open Government: A cognitive theory view of implementation barriers towards open government data. Public Management Review, v. 18, n. 9, p. 1335-1364, 2016.

WORTHY, B. the Impact of Open Data in the Uk: Complex, Unpredictable, and Political. Public Administration, v. 93, n. 3, p. 788-805, 2015.

YANG, T. M.; WU, Y. J. Examining the socio-technical determinants influencing government agencies' open data publication: A study in Taiwan. Government Information Quarterly, v. 33, n. 3, p. 378-392, 2016.

YANNOUKAKOU, A.; ARAKA, I. Access to Government Information: Right to Information and Open Government Data Synergy. Procedia - Social and Behavioral Sciences, v. 147, p. 332-340, 2014.

ZELETI, F. A.; OJO, A.; CURRY, E. Exploring the economic value of open government data. Government Information Quarterly, v. 33, n. 3, p. 535-551, 2016.

ZUIDERWIJK, A.; JANSSEN, M. Open data policies, their implementation and impact: A framework for comparison. Government Information Quarterly, v. 31, n. 1, p. 17-29, 2014.

ZUIDERWIJK, A.; JANSSEN, M.; CHOENNI, S.; MEIJER, R. Design principles for improving the process of publishing open data. Transforming Government: People, Process and Policy, v. 8, n. 2, p. 185-204, 2014. 


\section{APPENDIX A - SELECTED STUDIES*}

\begin{tabular}{|c|c|c|c|c|c|c|c|c|c|c|c|c|c|c|c|c|c|}
\hline \multirow[b]{2}{*}{ Reference } & \multicolumn{7}{|c|}{ DIMENSIONS } & \multicolumn{10}{|c|}{ APPROACHES } \\
\hline & 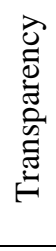 & 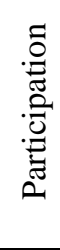 & $\begin{array}{l}\tilde{0} \\
.0 \\
0 \\
0 \\
\Xi \\
\Xi\end{array}$ & $\begin{array}{l}0 \\
0 \\
\mathscr{0} \\
\approx\end{array}$ & 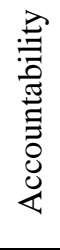 & 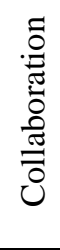 & $\begin{array}{l}\frac{0}{\pi} \\
\frac{\pi}{\pi} \\
\frac{d}{8} \\
\frac{\pi}{2}\end{array}$ & $\frac{3}{0}$ & 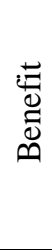 & $\frac{4}{2}$ & $\begin{array}{l}\stackrel{3}{\vec{\Xi}} \\
\stackrel{\Xi}{0}\end{array}$ & 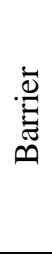 & 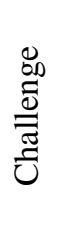 & 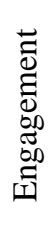 & 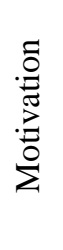 & 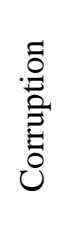 & 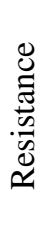 \\
\hline Arribas-Bel (2014) & $\mathrm{X}$ & $\mathrm{X}$ & & & & $\mathrm{X}$ & & $\mathrm{X}$ & $\mathrm{X}$ & & $\mathrm{X}$ & $\mathrm{X}$ & $\mathrm{X}$ & & & $\mathrm{X}$ & \\
\hline Bakici et al. (2013) & & $\mathrm{X}$ & $\mathrm{X}$ & & & & $\mathrm{X}$ & $\mathrm{X}$ & & $\mathrm{X}$ & & & & $\mathrm{X}$ & & & \\
\hline Bertot et al. (2014) & $\mathrm{X}$ & $\mathrm{X}$ & $\mathrm{X}$ & $\mathrm{X}$ & & $\mathrm{X}$ & & $\mathrm{X}$ & $\mathrm{X}$ & $\mathrm{X}$ & $\mathrm{X}$ & & & $\mathrm{X}$ & & & \\
\hline $\begin{array}{l}\text { Buckingham Shum et } \\
\text { al. (2012) }\end{array}$ & $\mathrm{X}$ & $\mathrm{X}$ & $\mathrm{X}$ & $\mathrm{X}$ & & $\mathrm{X}$ & & $\mathrm{X}$ & $\mathrm{X}$ & $\mathrm{X}$ & & $\mathrm{X}$ & $\mathrm{X}$ & $\mathrm{X}$ & $\mathrm{X}$ & & \\
\hline $\begin{array}{l}\text { Conradie and } \\
\text { Choenni (2014) }\end{array}$ & $X$ & $\mathrm{X}$ & $\mathrm{X}$ & & & & & $\mathrm{X}$ & $\mathrm{X}$ & $\mathrm{X}$ & $\mathrm{X}$ & $\mathrm{X}$ & & & & & \\
\hline Davis et al. (2010) & & $\mathrm{X}$ & & $\mathrm{X}$ & & $\mathrm{X}$ & & $\mathrm{X}$ & $\mathrm{X}$ & $\mathrm{X}$ & $\mathrm{X}$ & $\mathrm{X}$ & $\mathrm{X}$ & & & & \\
\hline Ding et al. (2011) & $\mathrm{X}$ & $X$ & & $\mathrm{X}$ & & & & $\mathrm{X}$ & $\mathrm{X}$ & & $\mathrm{X}$ & & & & & & \\
\hline Hendler et al. (2012) & $\mathrm{X}$ & $\mathrm{X}$ & $\mathrm{X}$ & & & & & & $\mathrm{X}$ & & & $\mathrm{X}$ & $\mathrm{X}$ & & & & \\
\hline Janssen (2011) & $\mathrm{X}$ & $\mathrm{X}$ & $\mathrm{X}$ & & $\mathrm{X}$ & & & $\mathrm{X}$ & $\mathrm{X}$ & $\mathrm{X}$ & & $\mathrm{X}$ & $\mathrm{X}$ & & $\mathrm{X}$ & & \\
\hline $\begin{array}{l}\text { Janssen and } \\
\text { Zuiderwijk (2014) }\end{array}$ & $\mathrm{X}$ & $\mathrm{X}$ & $\mathrm{X}$ & $\mathrm{X}$ & & & $\mathrm{X}$ & & $\mathrm{X}$ & $\mathrm{X}$ & & $\mathrm{X}$ & $\mathrm{X}$ & $\mathrm{X}$ & $\mathrm{X}$ & & \\
\hline Janssen et al. (2012) & $\mathrm{X}$ & $\mathrm{X}$ & $\mathrm{X}$ & $\mathrm{X}$ & $\mathrm{X}$ & & $\mathrm{X}$ & $\mathrm{X}$ & $\mathrm{X}$ & $\mathrm{X}$ & $\mathrm{X}$ & $\mathrm{X}$ & $\mathrm{X}$ & $\mathrm{X}$ & $\mathrm{X}$ & & \\
\hline $\begin{array}{l}\text { Kalampokis et al. } \\
\text { (2011) }\end{array}$ & $\mathrm{X}$ & $\mathrm{X}$ & & $\mathrm{X}$ & $\mathrm{X}$ & & $\mathrm{X}$ & $\mathrm{X}$ & $\mathrm{X}$ & & $\mathrm{X}$ & $\mathrm{X}$ & $\mathrm{X}$ & & & & \\
\hline Kassen (2013) & $\mathrm{X}$ & $\mathrm{X}$ & & & $\mathrm{X}$ & & & $\mathrm{X}$ & $\mathrm{X}$ & & & $\mathrm{X}$ & $\mathrm{X}$ & $\mathrm{X}$ & $\mathrm{X}$ & & \\
\hline Lee and Kwak (2012) & $\mathrm{X}$ & $\mathrm{X}$ & $\mathrm{X}$ & & $\mathrm{X}$ & $\mathrm{X}$ & & $\mathrm{X}$ & $\mathrm{X}$ & $\mathrm{X}$ & $\mathrm{X}$ & $\mathrm{X}$ & $\mathrm{X}$ & $\mathrm{X}$ & $\mathrm{X}$ & & \\
\hline O'Riain et al. (2012) & $\mathrm{X}$ & & $\mathrm{X}$ & $\mathrm{X}$ & & & $\mathrm{X}$ & & & $\mathrm{X}$ & $\mathrm{X}$ & $\mathrm{X}$ & $\mathrm{X}$ & & & & \\
\hline $\begin{array}{l}\text { Sayogo and Pardo } \\
\text { (2013) }\end{array}$ & & & & $\mathrm{X}$ & & $\mathrm{X}$ & $\mathrm{X}$ & $\mathrm{X}$ & & & $\mathrm{X}$ & $\mathrm{X}$ & $X$ & & $\mathrm{X}$ & & \\
\hline $\begin{array}{l}\text { Shadbolt and O'Hara } \\
\text { (2013) }\end{array}$ & & $\mathrm{X}$ & & $\mathrm{X}$ & $\mathrm{X}$ & & & $\mathrm{X}$ & $\mathrm{X}$ & $\mathrm{X}$ & & & & & & & \\
\hline Shadbolt, et al. (2012) & $\mathrm{X}$ & & & $\mathrm{X}$ & & & & $\mathrm{X}$ & $\mathrm{X}$ & & $\mathrm{X}$ & $\mathrm{X}$ & $\mathrm{X}$ & $\mathrm{X}$ & & & \\
\hline $\begin{array}{l}\text { Veljković et al. } \\
\text { (2014) }\end{array}$ & $\mathrm{X}$ & $\mathrm{X}$ & & & $\mathrm{X}$ & $\mathrm{X}$ & & & $\mathrm{X}$ & & $\mathrm{X}$ & $\mathrm{X}$ & & $\mathrm{X}$ & $\mathrm{X}$ & $\mathrm{X}$ & \\
\hline $\begin{array}{l}\text { Zuiderwijk and } \\
\text { Janssen (2014) }\end{array}$ & $\mathrm{X}$ & $\mathrm{X}$ & $\mathrm{X}$ & $\mathrm{X}$ & & $\mathrm{X}$ & & $\mathrm{X}$ & $\mathrm{X}$ & $\mathrm{X}$ & $\mathrm{X}$ & $\mathrm{X}$ & $\mathrm{X}$ & & $\mathrm{X}$ & & $\mathrm{X}$ \\
\hline
\end{tabular}

* List of 20 most popular articles that discuss each dimension. For a complete list of the 193 articles analyzed, please contact the authors. 